\title{
EFEKTIVITAS DAUN ZODIA (Evodia suaveolens) SEBAGAI REPELLENT NYAMUK AEDES AEGYPTI
}

\author{
Made Sudiarti $^{1 *}$, Mei Ahyanti ${ }^{2}$, Prayudhy Yushananta ${ }^{3}$ \\ 1,2 Department of Environmental Health, Poltekkes Kemenkes Tanjungkarang
}

\section{Artikel Info :}

Received 10 Agustus 2020

Accepted 20 April 2021

Available online 30 April 2021

Editor: Ahmad Fikri

Keyword:

$D H F$, concentration, time, repellent, zodia

Kata kunci :

$D B D$, konsentrasi, waktu, repellent, zodia
Ruwa Jurai: Jurnal

Kesehatan Lingkungan is licensed under a Creative Commons Attribution-

NonCommercial 4.0 International License.

\begin{abstract}
Dengue fever (DHF) is an infectious disease caused by the dengue virus through the Aedes aegypti mosquito vector. The use of repellents is an effort to prevent mosquito bites. One of the potential natural ingredients used as a repellent is zodia leaves (Evodia suaveolens) because they contain up to $46 \%$ linalool. This study aims to measure the effectiveness of the essential oil from zodia leaves as a repellent. The study was conducted on a laboratory scale following WHOPES recommendations. A total of 960 adult Ae.aegypti mosquitoes (aged 2-5 days) from the rearing process were used in this study. Five volunteers participated as probands. The essential oil is distilled from fresh azola leaves with $70 \%$ ethanol as solvent. The repellent lotion is made using an essential oil, lanolin, stearic acid, and other substance. The experiment used an arm-in-cage with two replication and 20 mosquitoes for each treatment. The concentrations tested were 1\%, $2 \%, 3 \%$, with $0 \%$ control. The number of mosquitoes that arrived was recorded after using the repellent for 15, 30,60, 120, 240, and 360 minutes. The study found a significant effect of concentration ( $p$-value $<0.0001)$ and contact time ( $p$-value $<0.0001)$ on the number of mosquitoes that landed. Zodia leaf lotion (Evodia suaveolens) with a concentration of $3 \%$ can protect $50 \%$ up to 360 minutes after use. Further research is needed to get a concentration that can provide $95 \%$ protective power after 30 minutes of use and 90\% after 360 minutes.
\end{abstract}

Demam berdarah (DBD) merupakan penyakit infeksi yang disebabkan oleh virus Dengue melalui vektor nyamuk Aedes aegypti. Penggunaan repellent merupakan upaya pencegahan gigitan nyamuk. Salah satu bahan alami yang dapat digunakan sebagai repellent adalah daun zodia (Evodia suaveolens) karena memiliki kandungan linalool hingga 46\%. Penelitian bertujuan mengukur efektifitas minyak asiri dari daun zodia sebagai repellent. Penelitian dilakukan pada skala laboroatorium mengikuti rekomendasi WHOPES. Sebanyak 960 ekor nyamuk Ae.aegypti dewasa (umur 2-5 hari) dari proses rearing digunakan dalam penelitian. Lima orang relawan berpartisipasi sebagai probandus. Minyak asiri didestilasi dari daun azola segar dengan pelarut etanol 70\%. Losion repellent dibuat menggunakan asiri, lanolin, asam stearat, setil alkohol, dimetikon, propilenglikol, paraffin cair, isopropyl miristat dan BHT, pada pemanasan basah suhu $70-75^{\circ} \mathrm{C}$. Percobaan menggunakan arm-in-cage dengan dua kali pengulangan, dan 20 ekor nyamuk setiap perlakuan. Konsentrasi yang diuji adalah 1\%, 2\%, 3\%, dengan kontrol $0 \%$. Pengamatan dilakukan dengan mencatat jumlah nyamuk yang hingga setelah penggunaan repellent selama 15, 30, 60, 120, 240, dan 360 menit. Penelitian mendapatkan pengaruh yang signifikan dari konsentrasi ( $p$-value $<0,0001)$ dan waktu kontak ( $p$-value $<0,0001)$ terhadap jumlah nyamuk yang hinggap. Losion daun zodia (Evodia suaveolens) dengan konsentrasi 3\% mampu memberikan proteksi di atas 50\% hingga 360 menit setelah penggunaan. Perlu penelitian lanjutan untuk mendapatkan konsentrasi yang dapat memberikan daya proteksi $95 \%$ setelah 30 menit pemakaian, dan 90\% setelah 360 menit pemakaian.

*Corresponding author: Made Sudiarti

J. Soekarno-Hatta No 6, Bandar Lampung, Provinsi Lampung

Email: madesudiarti126@gmail.com

\section{PENDAHULUAN}

Penyakit Demam Berdarah Dengue (DBD) merupakan salah satu penyakit yang disebabkan oleh virus Dengue dan ditularkan oleh nyamuk Aedest aegypti betina (Butarbutar et al., 2019; Yushananta \& Ahyanti, 2014). Di Indonesia kasus 
penyakit DBD pada tahun 2018 sebanyak 65.602 kasus (Incidence Rate $=24,73$ per 100.000 penduduk, jumlah kematian sebanyak 462 jiwa (Case Fatality Rate $=0,70 \%$ ). Di Provinsi Lampung, jumlah kasus DBD pada tahun 2018 sebanyak 2.872 kasus dengan kematian 14 orang (CFR= $0,49 \%, \quad I R=34,41$ per 100.000 penduduk) (Kemenkes RI, 2019). Hingga kini belum ada petunjuk tentang ditemukannya obat ataupun vaksin yang dapat membunuh virus Dengue, oleh karenanya kewaspadaan dini terhadap kasus DBD perlu ditingkatkan (Wulandari \& Ahyanti, 2018). Pengendalian secara kimia dapat dilakukan dengan penggunaan repellent. Repellent mudah didapatkan di pasaran dengan kandungan Diethyltoluamide (DEET) 130 g/L (Wirastuti \& Marlik, 2016).

$D E E T$ bekerja menghambat reseptor kimia karbondioksida dan asam laktat pada nyamuk. Namun, jika digunakan secara terus menerus akan membuat nyamuk menjadi resisten dan juga akan berdampak buruk terhadap kesehatan manusia. Untuk menghindari efek buruk tersebut, pembuatan repellent dapat memanfaatkan senyawa yang terkandung pada tanaman yang aman saat digunakan oleh pemakai (Marini \& Sitorus, 2019; Susanti \& Sari, 2019; Wirastuti \& Marlik, 2016) (Utomo \& Supriyatna, 2014).

Tanaman daun Zodia (Evodia suaveolens) merupakan salah satu tanaman sumber antioksidan alami. Keuntungan dari penggunaan ekstrak daun zodia adalah mudah ditemukan di sekitar pemukiman dan aman untuk digunakan dalam jangka panjang. Tanaman daun zodia juga tidak menyebabkan iritasi terhadap kulit, baunya tidak menyengat, tidak lengket, tidak beracun dan tidak meninggalkan noda pada pakaian. Penggunaan bahan alami dari ekstrak daun zodia diharapkan lebih aman jika dibandingkan dengan bahan kimia DEET (Mahmudi, Santoso, \& Laili, 2019). Bahan baku daun Zodia tidak perlu impor atau dapat dipenuhi dari dalam negeri, untuk itu perlu digali dan terus diteliti agar daya proteksi bahan alami ini mampu disejajarkan dan bersaing dengan losion anti nyamuk berbahan aktif kimia sintetik (Werdiningsih \& Amalia, 2018). Penelitian ini bertujuan untuk mengetahui kemampuan penurunan konsentrasi ekstrak daun zodia (Evodia suaveolens) sebagai repellent nyamuk.

\section{BAHAN dan METODE}

Penelitian menggunakan rancangan acak lengkap (RAL), dengan dua kali ulangan. Prosedur mengikuti rekomendasi World Health Organization Pesticides Evaluation Scheme (WHOPES, 2009). Percobaan dilakukan dengan empat variasi konsentrasi ekstrak daun Zodia $(0 \%, 1 \%$, $2 \%$, dan $3 \%)$, dan enam waktu pengamatan $(15,30,60,120,240,360$ menit).

Hewan uji adalah nyamuk jenis Aedes aegypti dewasa usia 2-5 hari. Telur nyamuk diperoleh dari Lokalitbang P2B2 Baturaja, Sumatera Selatan. Selanjutnya dilakukan pemeliharaan (rearing) hingga nyamuk mencapai usia 2-5 hari untuk digunakan sebagai bahan percobaan. Jumlah nyamuk yang digunakan pada setiap perlakuan sebanyak 20 ekor, sehingga jumlah total yang digunakan sebanyak 960 ekor (18 perlakuan dan 2 replikasi). Kriteria sampel nyamuk adalah jenis Aedes aegypti, nyamuk yang dapat terbang, berusia 2-5 hari, dan sudah dipuasakan selama 24 jam.

Daun zodia yang digunakan adalah daun segar, berwarna hijau agak kekuningan, pipih panjang dan lentur. Daun dibersihkan dengan air mengalir dan dikeringkan selama 24 jam pada suhu kamar agar senyawa yang terkandung dalam daun tidak rusak oleh sinar matahari. Setelah kering, dipotong kecil-kecil untuk membuka kelenjar minyak asiri sehingga dapat mempercepat proses ekstraksi. Hasil maserasi disaring untuk mendapatkan filtrat. Filtrat didistilasi untuk memisahkan minyak asiri dengan pelarutnya pada suhu $78^{\circ} \mathrm{C}$. Proses tersebut berlangsung selama sekitar tiga jam.

Pembuatan losion daun zodia dilakukan dengan melebur lanolin, asam stearat, setil alkohol, dimetikon, propilenglikol, paraffin cair, isopropyl miristat dan BHT, dalam cawan penguap menggunakan waterbath pada suhu $70-75^{\circ} \mathrm{C}$. TEA didispersikan terlebih dahulu dengan sejumlah air, lalu dihomogenkan secara perlahan dan dipanaskan dalam cawan penguap dengan waterbath pada suhu $70-75^{\circ} \mathrm{C}$. Metil paraben dan propil paraben masing-masing dilarutkan dalam air panas, lalu keduanya kemudian dicampur. TEA dicampurkan sedikit demi sedikit ke dalam fase minyak dalam mortir yang telah dipanaskan sampai terbentuk masa losion yang stabil. Pencampuran dilakukan hingga suhu mencapai $40-45^{\circ} \mathrm{C}$. 
Pengujian menggunakan lima orang relawan (probandus) menggunakan studi arm-in-cage. Sebanyak 20 ekor nyamuk dimasukkan ke dalam kandang uji, dan probandus memasukan lengan yang telah diberi lotion repellent sesuai konsentrasi yang ditetapkan. Uji repellent mengacu pada metode yang dilakukan oleh Fradin \& Day, (2002) dengan dimodifikasi. Kriteria probandus adalah dewasa (usia 18-55 tahun), tidak menggunakan produk pewangi atau repellant selama 12 jam terakhir, tidak merokok selama 12 jam terakhir, sehat yang dibuktikan dari surat keterangan dokter, tidak memiliki riwayat penyakit DBD, dan menandatangani surat persetujuan.

Data yang terkumpul dianalisis dengan perangkat SPSS. Uji statistik menggunakan ANOVA two-way untuk mengetahui pengaruh konsentrasi, waktu kontak, serta kombinasi konsentrasi dan waktu kontak. Keseluruhan prosedur penelitian telah mendapatkan izin etik dari Komisi Etik Penelitian Kesehatan (KEPK) Politeknik Kesehatan Tanjungkarang dengan nomor 213/KEPK-TJK/III/2020.

\section{HASIL}

\section{Kosentrasi}

Rerata jumlah nyamuk yang hinggap pada tangan probandus, tertinggi pada konsentrasi $0 \%$ yaitu sebanyak 12,25 ekor ( $S D=3,19$ ekor) dan terendah pada konsentrasi $3 \%$ yaitu sebanyak 4,58 ekor ( $S D=2,91$ ekor). Dari Gambar 1a terlihat bahwa semakin tinggi konsentrasi, maka semakin rendah jumlah nyamuk yang hinggap.

Hasil statistik menggunakan ANOVA two-way (Tabel 3) menunjukkan perbedaan signifikan jumlah nyamuk yang hinggap berdasarkan konsentrasi ( $p$-value $<0,0001)$.

Tabel 2. Jumlah nyamuk hinggap berdasarkan konsentrasi

\begin{tabular}{lllll}
\hline Konsentrasi & Min & Max & Men & SD \\
\hline $0 \%$ & 8 & 18 & 12,25 & 3,19 \\
$1 \%$ & 5 & 11 & 8,50 & 1,78 \\
$2 \%$ & 5 & 10 & 7,50 & 1,45 \\
$3 \%$ & 2 & 13 & 4,58 & 2,91 \\
\hline
\end{tabular}

\section{Waktu Kontak}

Berdasarkan waktu (Gambar 1), jumlah nyamuk hinggap terendah hingga menit ke-15 sebanyak 6,13 ekor $(S D=3,48)$, dan tertinggi setelah 360 menit yaitu sebanyak 11,38 ekor $(S D=4,53)$. Pada Gambar $1 \mathrm{~b}$ terlihat bahwa semakin lama waktu, maka semakin banyak nyamuk yang menghinggapi tangan probandus. Hasil uji statistik (Tabel 3) menunjukkan perbedaan nyata jumlah nyamuk yang hinggap berdasarkan waktu kontak ( $p$-value $<0,0001$ ).

Tabel 2. Jumlah nyamuk hingga berdasarkan waktu

\begin{tabular}{lllll}
\hline Waktu & Min & Max & Mean & SD \\
\hline 15 menit & 2 & 13 & 6,13 & 3,48 \\
30 menit & 3 & 10 & 7,38 & 2,62 \\
60 menit & 4 & 10 & 7,00 & 1,85 \\
120 menit & 4 & 12 & 8,13 & 2,90 \\
240 menit & 2 & 15 & 9,25 & 4,20 \\
360 menit & 4 & 18 & 11,38 & 4,53 \\
\hline
\end{tabular}

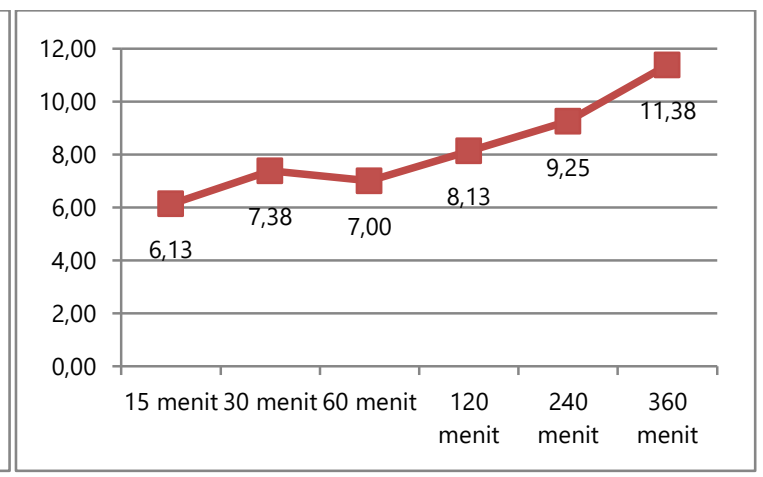

Gambar 1. Rerata nyamuk hinggap berdasarkan konsentrasi (a), dan waktu (b)

\section{Kosentrasi dan waktu Kontak}

Pada Tabel 3 terlihat bahwa jumlah nyamuk yang hinggap pada tangan probandus tidak menunjukkan perbedaan yang nyata berdasarkan interaksi konsentrasi dan waktu kontak ( $p$-value $=0,339$ ).

Walaupun tidak menunjukkan perbedaan nyata, namun pada Gambar 2 terlihat bahwa 
hanya pada konsentrasi 3\% jumlah nyamuk hinggap kurang dari lima ekor. Temuan lain menunjukkan bahwa kemampuan repellent pada konsentrasi 3\% bertahan hingga 240 menit. Pada percobaan ini disimpulkan bahwa konsentrasi efektif daun azola sebagai repellent pada konsentrasi $3 \%$.

Tabel 3. Hasil analisis ANOVA Two Way

\begin{tabular}{llllll}
\hline Variabel & df & Sum of Square & Mean square & $F$ & p-value \\
\hline Konsentrasi & 3 & 360,75 & 120,250 & 41,229 & $<0,0001$ \\
Waktu Kontak & 5 & 140,91 & 28,183 & 9,663 & $<0,000$ \\
Konsentrasi*Waktu kontak & 15 & 52,25 & 3,483 & 1,194 & 0,339 \\
\hline
\end{tabular}

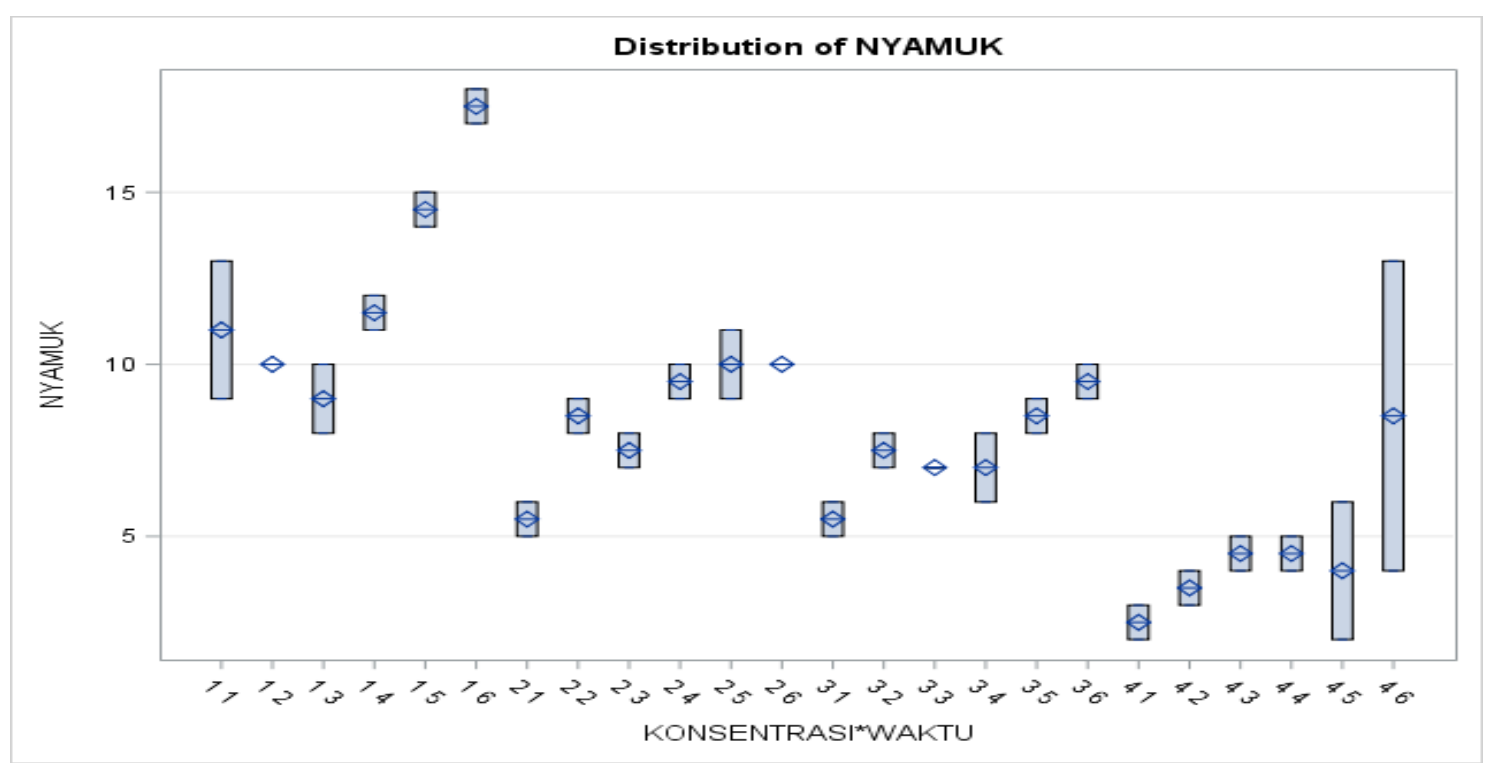

Gambar 2. Rerata nyamuk hinggap berdasarkan interaksi konsentrasi dan waktu

Daya proteksi adalah kemampuan bahwa daya proteksi di atas $50 \%$ hanya pada perlindungan kulit yang diberi perlakuan konsentrasi repellent $3 \%$. Kemampuan proteksi (repellent) dibandingkan kontrol, dinyatakan pada 30 menit sebesar 65,0\%, dan setelah 360 dalam persen (WHO, 2009). Pada Tabel 4 terlihat menit (6 jam) sebesar 51,4\%.

Tabel 4. Daya proteksi repellent berdasarkan konsentrasi dan waktu

\begin{tabular}{llllllll}
\hline \multirow{2}{*}{ Konsentrasi } & \multicolumn{2}{l}{ Waktu (menit) } & & & & \multirow{2}{*}{ Rerata } \\
\cline { 2 - 8 } $1 \%$ & 15 & 30 & 60 & 120 & 240 & 360 & \\
\cline { 2 - 8 } $2 \%$ & 50,0 & 15,0 & 16,7 & 17,4 & 31,0 & 42,9 & 28,8 \\
$3 \%$ & 50,0 & 25,0 & 22,2 & 39,1 & 41,4 & 45,7 & 37,2 \\
\hline
\end{tabular}

\section{PEMBAHASAN}

Repellent merupakan insektisida yang digunakan untuk mencegah nyamuk menghisap darah. Repellent losion merupakan repellent yang mempunyai bahan aktif untuk mengusir nyamuk dalam waktu sementara, selain itu losion adalah pelembap yang digunakan untuk melembapkan kulit dan menghaluskan kulit. Penelitian ini menggunakan nyamuk Aedes aegypti yang dipelihara dari telur yang diperoleh dari Lokalitbang P2B2 Baturaja, Sumatera Selatan. Nyamuk yang digunakan pada saat 
penelitian adalah nyamuk yang mempunyai umur sesuai standar WHO yaitu 2-5 hari. Pada umur tersebut ketahanan tubuh nyamuk sudah mulai kuat dan sudah produktif. Pada umur di bawah 2 hari, keadaan fisiknya masih lemah sehingga akan mempermudah terjadinya kematian pada nyamuk. Sedangkan umur di atas 5 hari, ketahanan tubuh nyamuk telah menurun dan meningkatkan risiko kematian. Proses penetasan telur menjadi nyamuk dewasa dilakukan pada waktu yang sama, sehingga seluruh nyamuk uji memiliki umur yang seragam.

\section{Konsentrasi}

Hasil penelitian mendapatkan rerata jumlah nyamuk yang hinggap terendah pada konsentrasi 3\% (Tabel 1) yaitu sebanyak 4,58 ekor (SD = 2,91 ekor). Hasil statistik menunjukkan pengaruh konsentrasi terhadap jumlah nyamuk hingga ( $p$-value $<0,0001$ ); semakin tinggi konsentrasi, maka semakin sedikit nyamuk yang hinggap. Hasil ini membuktikan efektivitas tertinggi daun zodia (Evodia suaveolens) sebagai repellent pada konsentrasi 3\%.

Penelitian sesuai dengan Nindatu dan Noya, semakin tinggi konsentrasi minyak asiri maka semakin sedikit nyamuk yang hinggap pada hewan uji (Nindatu \& Noya, 2018). Setelah dioleskan ke kulit, minyak asiri akan terserap ke dalam pori kulit, selanjutnya akan menguap akibat adanya panas tubuh, bau inilah yang terdeteksi oleh reseptor kimia nyamuk (Firdausi, Andrie, \& Luliana, 2015; Husna, Andrie, \& Luliana, 2015).

Nyamuk tidak mau mendekati tangan probandus disebabkan kandungan linalool pada minyak asiri dari daun zodiac Linalool merupakan suatu senyawa terpenoid alkohol yang dapat ditemukan secara alami pada minyak asiri tanaman, bunga dan rempah-rempah, dan dapat digunakan sebagai repellent terhadap nyamuk. Kandungan senyawa Linalool tertinggi berada pada tanaman daun kemangi (Ocimum santum) sebesar 56,7\%, bunga lavender (Lavandula angustifolia) sebesar 47,7\%, dan zodia (Evodia sauveolens) sebanyak 46\% (Agustina et al., 2019; Mahmudi et al., 2019; Werdiningsih \& Amalia, 2018). Kandungan linalool pada daun zodia berfungsi sebagai racun kontak dengan efek meningkatkan aktivitas saraf sensoris pada serangga dan menyebabkan stimulasi saraf motorik sehingga menyebabkan kejang dan kelumpuhan (Mahmudi, Santoso, \& Laili, 2019).

Antena dan palp pada nyamuk yang berfungsi sebagai alat indera kimia sangat sensitif dan dapat terangsang oleh bau kimia. Bau minyak asiri yang dilepaskan dari kulit manusia akan menguap dan terdeteksi oleh chemoreceptor indera nyamuk dan dilanjutkan ke impuls saraf. Bau ini tidak disenangi nyamuk karena dapat menyebabkan keadaan bingung, sehingga otak akan memberikan respons agar nyamuk menghindar dari bau tersebut. Minyak asiri juga bekerja dengan cara menutupi bau pada manusia sehingga reseptor-reseptor pada alat indera tersebut terganggu dan nyamuk tidak dapat mendeteksi produk kimiawi dari manusia (Firdausi et al., 2015; Husna et al., 2015; Utomo \& Supriyatna, 2014).

\section{Waktu Kontak}

Hasil penelitian mendapatkan bahwa rerata jumlah nyamuk yang hinggap pada tangan probandus paling banyak setelah 360 menit, sebanyak 11,38 ekor ( $S D=4,53)$. Hasil uji statistik menunjukkan pengaruh lama waktu terhadap jumlah nyamuk yang hinggap ( $p$-value $<0,0001$ ). Semakin lama waktu kontak, maka semakin banyak nyamuk yang hinggap.

Mekanisme kerja repellent setelah dioleskan merata ke permukaan kulit, akan meresap melalui pori-pori. Adanya panas tubuh maka minyak asiri dari repellent akan menguap sedikit demi sedikit. Bau akan terdeteksi oleh chemoreceptor pada antena nyamuk dan diteruskan ke impuls saraf. Karena bau tidak disukai, maka nyamuk akan menghindar dari sumber bau tersebut.

Lamanya waktu losion repellent bertahan pada kulit bergantung pada banyaknya aktifitas dari manusia. Semakin banyak aktivitas, maka akan semakin tinggi suhu tubuh dan semakin cepat proses penguapan Linalool. Selain itu, aktivitas tinggi akan meningkatkan produksi keringat. Linalool yang terserap dalam kulit akan keluar bersama keringat, sehingga lama kelamaan akan habis. Pada penelitian ini, lebih dari separuh nyamuk $(n=20)$ hinggap di tangan 
probandus setelah 360 menit penggunaan losion.

Kecepatan penguapan Linalool dari tubuh juga dipengaruhi oleh suhu udara. Suhu udara yang tinggi akan meningkatkan suhu tubuh, dan mekanisme adaptasi tubuh akan meningkatkan produksi keringat (Kukus, Supit, \& Lintong, 2013; Sandi, Ariyasa, Teresna, \& Ashadi, 2017). Selain itu, nyamuk juga lebih menyukai suasana yang hangat, sehingga suhu tubuh akan mempengaruhi banyaknya jumlah nyamuk yang hinggap (Sanjaya, Adisenjaya, Yusuf, \& Wijayanti, 2014). Pada suhu lingkungan yang tinggi, nyamuk akan meningkatkan frekuensi menggigit (Rusli \& Yushananta, 2020; Yushananta, Setiawan, \& Tugiyono, 2020), dan aktivitasnya dalam mencari makanan (Sanjaya et al., 2014).

\section{Konsentrasi dan Waktu Kontak}

Daya proteksi adalah kemampuan perlindungan kulit yang diberi perlakuan (repellent) dibandingkan kontrol (WHO, 2009). Pada penelitian ini, daya proteksi di atas 50\% hanya pada konsentrasi repellent $3 \%$, tertinggi setelah pemakaian 15 menit $(77,3 \%)$ dan terendah setelah 360 menit (51,4\%). Hasil ini menyimpulkan bahwa konsentrasi 3\% merupakan konsentrasi yang paling baik digunakan sebagai repellent.

Namun, hasil penelitian ini belum memenuhi standar dari Komisi Pestisida Indonesia (KPI) yang mensyaratkan daya proteksi repellent harus mencapai rata-rata $90 \%$ hingga jam keenam (Anindhita, Budiyono, 2015; Utomo \& Supriyatna, 2014). Demikian pula dengan standar WHOPES 2000 yang mengatakan bahwa suatu repellent dapat didaftarkan jika zat tersebut memberikan proteksi lebih dari 95\% selama minimal 30 menit (Utomo \& Supriyatna, 2014). Dari Gambar 2 diketahui bahwa kemampuan repellent tertinggi pada konsentrasi $3 \%$, hanya mampu memberikan proteksi hingga 240 menit $(72,4 \%)$.

Penurunan daya proteksi losion daun zodia dipengaruhi oleh tingginya penguapan bahan aktif (Linalool) dari kulit akibat suhu badan dan suhu udara. Selain itu, diduga akibat kurang homogennya losion pada proses pembuatan. Tingkat homogenitas losion anti nyamuk akan mempengaruhi daya proteksi terhadap nyamuk
(Utomo \& Supriyatna, 2014). Semakin turun daya proteksinya maka semakin rendah daya tolak dari ekstrak daun zodia (Fadilah, dkk 2017).

Penelitian Mirawati et al mendapatkan kemampuan proteksi minyak asiri zodia hingga enam jam pada konsentrasi $0,3 \%$ setelah dicampur dengan minyak asiri batang serai sebanyak 0,7\% (Mirawati, Simaremare, \& Pratiwi, 2018). Penelitian lain menyatakan daun zodia mampu menghalau nyamuk selama 6 jam, dengan daya proteksi 90 persen pada konsentrasi 4\% (Widawati, 2013). Pengembangan penelitian dapat dilakukan dengan peningkatan konsentrasi, pencampuran dengan bahan lain. Pertimbangan suhu tubuh dan suhu lingkungan harus dilakukan sebagai variabel luar yang ikut berkontribusi.

\section{SIMPULAN}

Penelitian mendapatkan bahwa losion daun zodia (Evodia suaveolens) dapat digunakan sebagai repellent nyamuk Aedest aegypti. Pada konsentrasi $3 \%$, repellent mampu memberikan proteksi di atas 50\%. Konsentrasi dan waktu kontak menunjukkan pengaruh signifikan terhadap jumlah nyamuk yang hinggap. Namun, interaksi kedua variabel belum menunjukkan perbedaan yang nyata. Kecepatan penguapan dipengaruhi suhu tubuh dan temperatur udara, diduga menjadi penyebab menurunnya kemampuan proteksi dari repellent. Perlu penelitian lebih lanjut untuk mendapatkan konsentrasi yang dapat memberikan daya proteksi 95\% setelah 30 menit pemakaian, dan 90\% setelah 360 menit pemakaian. Suhu tubuh probandus dan temperatur udara menjadi variabel luar yang harus diperhitungkan pada penelitian mendatang.

\section{DAFTAR PUSTAKA}

Agustina, A., Kurniawan, B., Yusran, M., Kedokteran, F., Lampung, U., Parasitologi, B., ... Lampung, U. (2019). Efektivitas Dari Tanaman Zodia ( Evodia Suaveolens ) Sebagai Insektisida Nabati Nyamuk Aedes aegypti Penyebab Demam Berdarah Effectiveness of Zodia ( Evodia Suaveolens ) Plants as Aedes aegypti Vegetable Insecticide Causes of Dengue Fever Divisio: Arthro. Medula, 9(2), 351-358.

Anindhita, Budiyono, H. (2015). Daya Tolak Repellent Bentuk Lotion Dengan Ekstrak Daun 
Alpukat (Persea americana Mill) Terhadap

Nyamuk Aedes aegypti Linn. 3(April).

Butarbutar, R. N., Sumampouw, O. J., \& Pinontoan, O. R. (2019). Trend Kejadian Demam Berdarah Dengue Di Kota Manado Tahun 2009-2018. KESMAS - Jurnal Kesehatan Masyarakat, 8(6), 364-370.

Firdausi, A., Andrie, M., \& Luliana, S. (2015). Aktivitas Repelan Minyak Atsiri Daun Jeruk Pontianak (Citrus nobilis Lour.) Terhadap Nyamuk Aedes aegypti L. Metode WHOPES. Asiswa Farmasi Fakultas Kedokteran UNTAN, 3(1), 1-9. https://doi.org/10.7788/boehlau.9783412215 101.186

Fradin, M. S., \& Day, J. F. (2002). Comparative efficacy of insect repellents against mosquito bites. New England Journal of Medicine, 347(1), 13-18. https://doi.org/10.1056/NEJMoa011699

Husna, Q. rahmawati, Andrie, M., \& Luliana, S. (2015). Aktivitas Repelen Minyak Atsiri Kulit Buah Jeruk Pontianak (Citrus nobilis Lour.) Terhadap Nyamuk Aedes aegypti L. dengan Metode Whopes. Jurnal Mahasiswa Farmasi Fakultas Kedokteran UNTAN, 3(1), 186-269. https://doi.org/10.7788/boehlau.9783412215 101.186

Kemenkes RI. (2019). Data dan Informasi profil Kesehatan Indonesia 2018. In R. Kurniawan, B. Hardhana, Yudianto, \& T. Siswanti (Eds.), Data dan Informasi Profil Kesehatan Indonesia. Jakarta: Pusat Data dan Informasi Kementerrian Kesehatan Republik Indonesia.

Kukus, Y., Supit, W., \& Lintong, F. (2013). Suhu Tubuh: Homeostasis Dan Efek Terhadap Kinerja Tubuh Manusia. Jurnal Biomedik (Jbm), 1(2). https://doi.org/10.35790/jbm.1.2.2009.824

Mahmudi, Santoso, H., \& Laili, S. (2019). Uji Insektisida Serai (Cymbopogon nardus) dan Daun Zodia (Evodia suaveolens) Terhadap Mortalitas Nyamuk (Aedes aegypti). Jurnal Ilmiah Sains Alami, 2(1), 44-49.

Marini, \& Sitorus, H. (2019). Beberapa tanaman yang berpotensi sebagai repelen di indonesia. Spirakel, 11(1), 24-33.

Mirawati, P., Simaremare, E. S., \& Pratiwi, R. D. (2018). Uji Efektivitas Repellent Sediaan Lotion Kombinasi Minyak Atsiri Daun Zodia (Evodia suaveolens Scheff) dan Minyak Atsiri Batang Serai (Cymbopogon citratus) Terhadap Nyamuk Aedes aegypti L.
PHARMACY: Jurnal Farmasi Indonesia

(Pharmaceutical Journal of Indonesia), 15(1), 1. https://doi.org/10.30595/pharmacy.v15i1.228 6

Nindatu, M., \& Noya, L. (2018). Efektifitas Daya Tolak Seduhan Daun Cengkeh (Syzgium arimaticum L) Terhadap Nyamuk Anopheles Sp. Jurnal Biologi Edukasi, 53(9), 1689-1699. https://doi.org/10.1017/CBO9781107415324. 004

Nur Fadilah, A. L., Cahyati, W. H., \& Windraswara, R. (2017). Uji Daya Proteksi Ekstrak Daun Pepaya (Carica papaya L) Dalam Sediaan Lotion Dengan Basis PEG400 Sebagai Repellent Terhadap Aedes aegypti. Care: Jurnal Ilmiah Ilmu Kesehatan, 4(3), 318. https://doi.org/10.33366/cr.v5i3.668

Rusli, Y., \& Yushananta, P. (2020). Climate variability and dengue hemorrhagic fever in Bandar Lampung, Lampung Province, Indonesia. International Journal of Innovation, Creativity and Change, 13(2), 323-336.

Sandi, I., Ariyasa, I., Teresna, I., \& Ashadi, K. (2017). Pengaruh Kelembaban Relatif Terhadap Perubahan Suhu Tubuh Latihan. Sport and Fitness Journal, 5(1), 103-109.

Sanjaya, Y., Adisenjaya, Yusuf, H., \& Wijayanti, L. (2014). Efektivitas Daya Tolak Ekstrak Geranium Radula Cavan terhadap Nyamuk Aedes aegypti (Linn.). Bionatura-JUrnal IlmuIlmu Hayati Dan Fisik, 16(2), 62-67.

Susanti, D., \& Sari, N. (2019). Inventarisasi Ragam Tumbuhan Obat Berpotensi sebagai Anti Nyamuk Inventory of Potential Medicinal Plants as Anti Mosquitoes. Jurnal Vektor Penyakit, 13(1), 7-20. https://doi.org/https://doi.org/10.22435/vekt orp.v13i1.447

Utomo, P. P., \& Supriyatna, N. (2014). Perbandingan daya proteksi losion anti nyamuk dari beberapa jenis minyak atsiri tanaman pengusir nyamuk. Biopropal Industri, 5(2), 79-84.

Werdiningsih, I., \& Amalia, R. (2018). Lotion Ekstrak Daun Zodia (Evodia sauveolens) Sebagai Repellent Nyamuk Aedes sp. Jurnal Vektor Penyakit, 12(2), 103-108. https://doi.org/10.22435/vektorp.v12i2.839

WHO. (2009). Report of the Thirteenth Whopes Working Group Meeting. In World Health Organization (Vol. 5). Geneva.

WHOPES. (2009). Guidelines for efficacy testing of mosquito repellents for human skin. 
Who/Htm/Ntd/Whopes/2009.4, 1-6.

Widawati, M. (2013). the effectiveness of fixative addition on zodia (Evodia suaveolens) and rosemary (Rosmarinus officinalis) gel against Aedes aegypti. (December).

Wirastuti \& Marlik. (2016). Kemampuan Efektifitas Ekstrak Daun Kenikir (Cosmos caudatus K) Dibandingkan dengan Soffell Aroma Kulit Jeruk sebagai Repellent Terhadap Nyamuk Aedes aegypti. Jurnal Penelitian Kesehatan, 7(2), 81-84.

Wirastuti, H. A., \& Marlik. (2016). Kemampuan Efektifitas Ekstrak Daun Kenikir (Cosmos caudatus K) Dibandingkan dengan Soffell Aroma Kulit Jeruk Sebagai Repellent Terhadap Nyamuk Aedes aegypti. Jurnal Penelitian Kesehatan Suara Forikes, VII(2), 8184.
Wulandari, K., \& Ahyanti, M. (2018). Efektivitas Ekstrak Biji Bintaro ( Cerbera manghas ) sebagai Larvasida Hayati pada Larva Aedes aegypti Instar III. Jurnal Kesehatan Politeknik Kesehatan Tanjungkarang, 9(2010), 218-224.

Yushananta, P., \& Ahyanti, M. (2014). Pengaruh Faktor Iklim Dan Kepadatan Jentik Ae.Aegypti Terhadap Kejadian DDB. Jurnal Kesehatan Lingkungan, $V(1), 1-10$.

Yushananta, P., Setiawan, A., \& Tugiyono, T. (2020). Variasi Iklim dan Dinamika Kasus DBD di Indonesia: Systematic Review. Jurnal Kesehatan, 11(2), 294. https://doi.org/10.26630/jk.v11i2.1696 